\title{
Determinants of Market Participation and Intensity of Participation of Teff Producers in West Arsi Zone of Oromia, Ethiopia
}

\author{
Kuftu Keno Dule ${ }^{1^{*}} \quad$ Aemro Tazeze ${ }^{2}$ \\ 1. Department of Agricultural Economics, College of Agriculture and Natural Resources, Dilla University, \\ Ethiopia \\ 2.School of Agricultural Economics and Agribusiness, College of Agriculture and Environmental Sciences, \\ Haramaya University, Ethiopia
}

\begin{abstract}
In Ethiopia, agricultural transformation is taken as a pathway to transition from a traditional subsistence orientation to market focused and commercialized farming system. In this regard, efforts to enhance smallholders' participation in cereal market in general and teff in particular have made through boosting production . Nevertheless there is dearth of information on the teff of market participation and its intensity of participation in central Oromia particularly in Shashamane district. Therefore, this study was analyzed market participation and extent of teff market participation of farmers. The total 202 respondents were selected by using two stage sampling techniques and also interviewed. Double hurdle model was used to identify the determinants of market participation decisions and extent of market participation. The study showed that, educational level, livestock owned, land allocation for teff production, extension contact had positive significant effect on teff market participation decision, while sex of household head, family size, distance to nearest market had significant and negative effect. Intensity of market participation was affected positively and significantly by land allocated for teff, while family size and non-farm income significantly and negatively affect level of teff mark supply Therefore, focus on strengthening the technical, resource base, infrastructural and institutional capacity building of smallholder farmers are strategies that promote teff producers market participation and Intensity of participation. Keywords: Double hurdle model, Smallholder farmers, Teff market participation
\end{abstract}

DOI: $10.7176 / \mathrm{FSQM} / 101-04$

Publication date:September $30^{\text {th }} 2020$

\section{INTRODUCTION}

Agricultural sector is a backbone of the Ethiopian economy accounting for $36.3 \%$ of overall GDP (NBE, 2018) and $70 \%$ of foreign exchange earnings and the sector provides employment for $72.7 \%$ of the population (USAID, 2018). In addition; it supplies 70\% of the raw-material requirements of local industries (ADEA, 2014; FAO, 2015; Zerihun et al., 2016). In Ethiopia $95.9 \%$ of the total area is cultivated by smallholder farmers and contribute $90 \%$ of the total agricultural output indicating the dominant contribution of smallholder farmers to the overall agricultural growth in the country and the entire movement of the agriculture sector depends on what is happening in smallholder farmers (USAID, 2018; Gebreslassie and Bekele, 2012).

In the agriculture sector, cereals are dominant in terms of both land area coverage and volume of production. Cereals cover about $80.71 \%$ of the total grain crop area $(10,232,582.23$ hectares) and contribute about $87.48 \%$ $(267,789,764.02$ quintals) of the grain production (CSA, 2018).Teff (Eragrostis tef) accounts for the largest share of total cultivated area $(23.85 \%)$ in $2017 / 18$ production season, followed by maize $(16.79 \%)$ and sorghum $(14.96 \%)$. But, in terms of total production, teff takes the second rank (17.26\%) next to maize (27.43\%) (CSA, 2018). Like other crops, teff can be exported to other countries.

Improved access to market plays an important role in improving rural incomes of smallholder farmers in subSaharan Africa. Despite this, participation of smallholder farmers in markets in most sub-Saharan African countries remains low due to a range of constraints. One of the limiting constraints faced by smallholder farmers is linked to poor market access. Poor infrastructure and weak institutions raise transaction costs that considerably alter production and market participation decisions. The majority of smallholder farmers are located in remote areas with poor transport and market infrastructures, contributing to the high transaction costs. Furthermore, the poor do not possess the level of assets required to protect themselves from market, natural, political and social shocks (Mmbando et al., 2015).

In Ethiopia, even though relatively high economic growth rates registered over past years and the agriculture sector has shown steady annual growth rates for over a decade, agricultural productivity is still at low levels and most of the food produced on the farm remains consumed by the farm household (ATA, 2015). Shashamane district is one of the potential producers of teff in west Arsi zone of Oromia region Ethiopia. Teff production in the district is both for consumption and market purpose. In the district, more than 10,000 ha of land are suitable for teff production. Teff yield in the district is $17.5 \mathrm{qt} / \mathrm{ha}$ (SHDAO, 2018). Slightly more than the national average of 
17.48qt/ha (CSA, 2018).

The welfare status of smallholder farmers is determined by the level they participate in a given market as seller. But, there is a dearth of information that enhances or retard smallholders in terms of decision to participate in teff market and extent of market participation of teff producer particularly in Shashamane district in central Ethiopia. Such information is essential for making knowledge-based decision that are geared towards improving market participation of farmers in teff and contribute to the national development goals of eradicating poverty and improving food security. Therefore, this study aims to emphasize on identifying factors affecting market participation and extent of market participation of teff producers in Shashamane district.

\section{METHODOLOGY}

The study was conducted in Shashamane District, West Arsi Zone of Oromia National Regional State, Ethiopia. The total population of the District is estimated to be 241,311 of which $55.09 \%$ and $44.9 \%$ are male and females respectively.

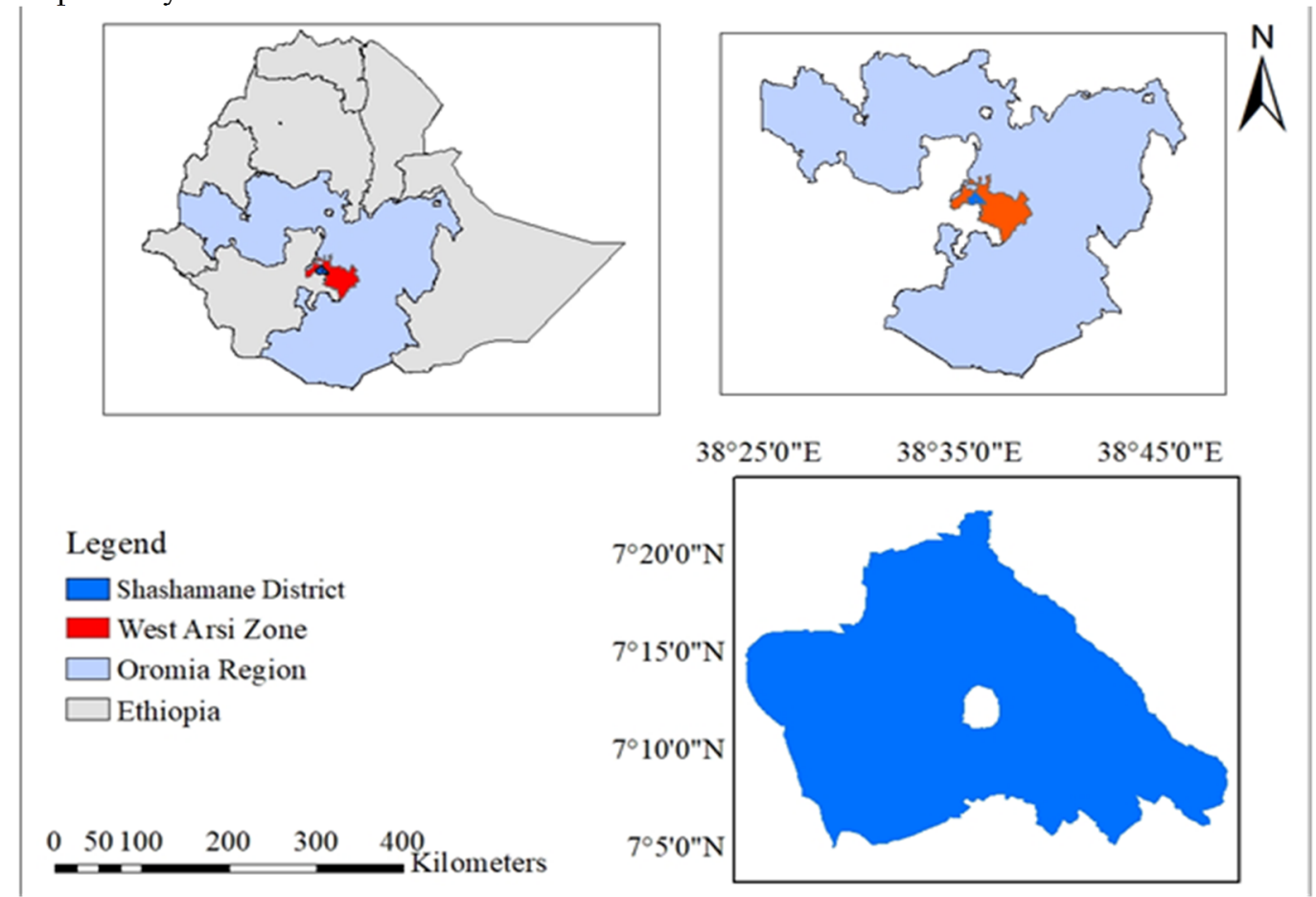

Figure 1. Geographical location of the study area

Source: Developed from Ethio-GIS (2006) and own sketch

Like in many other parts of Ethiopia, the farming system in Shashamane district is still traditional with oxen (animal's power), and labor as the major means of production during land preparation, planting and harvesting as well as post-harvest processes. Rain-fed agriculture is a common practice for many farm households in this district. This district has 37 rural kebeles and one town administration. Shashamane district is characterized by similar agro-climatic zones, which is midland. The average annual rainfall for the area ranges from 700 to $1450 \mathrm{~mm}$ with a temperature range of $12 \mathrm{C}^{\circ}$ to $27 \mathrm{C}^{\circ}$. The farmers of this district produce both in meher and belg seasons. They produce cereals such as teff, wheat, barley and maize, sorghum; pulses such as haricot bean, groundnut, and vegetables in some amounts. Overall; teff, barley, maize, wheat and groundnut are the major crops cultivated by the farmers in the study area. Moreover, Livestock production is also an important sub-sector undertaken in line with crop production which play important role in the economy of smallholder farmers of the district. A district has a potential for livestock production which is witnessed by farmers ownership livestock such as cattles, goats, sheep, horses, mules, donkey are livestock types that the district is endowed with (SHDAO, 2018)

This study used household survey data collected from the district. Both primary and secondary data were used in this study. Primary data were collected using structured questionnaire by trained enumerators. Secondary data helpful to the study were gathered from statistical abstract of Shashamane district, journals, research findings and different reports.

Two stage random sampling procedures were used for the selection of sample household heads. In the first stage, four kebeles were selected from thirty seven teff producer kebeles using simple random sampling technique. In the second stage, from the total of 2545 households in the selected four Kebeles, 202 sample household heads were randomly selected using probability proportional to size of teff producer households in four Kebeles, by using a formula developed by Yamane (1967). 


$$
\begin{aligned}
& n=\frac{N}{1+N(e)^{2}} \\
& \mathrm{~N}=22200 \text { (Total number of households in the study district) } \\
& \mathrm{e}=0.07
\end{aligned}
$$

Where, $\mathrm{n}$ is the sample size, $\mathrm{N}$ is the population size (population of interest) $\mathrm{e}$ is the level precision.

Descriptive analytical tools such as mean, percentage, frequencies, and the like were used to describe households' demographic and socio-economic characteristics, and others. T-test and chi-square test were also used to compare market participants and non-participants over demographic and socio-economic, and other factors.

So far, empirical studies on analysis of the smallholder market participation have used various analytical models depending up on their nature of dataset. This study have used double hurdle model to identify factors that influence smallholder teff market participation decision and intensity of teff sales in the study area. According to Cragg (1971), double-hurdle model evaluating two separate decisions regarding decision to participation in a teff output as seller and the extent of participation (intensity of teff sale) each of which is determined by a different set of explanatory variables can be specified as:

$$
\begin{gathered}
d_{i}^{*}=W_{i}^{\prime} \beta+v_{i} \quad v_{i} \sim N\left(\begin{array}{ll}
0 & 1
\end{array}\right) \\
d_{i}=\left\{\begin{array}{l}
1 i f d_{i}^{*}>0 \\
0 . i f d_{i}=0
\end{array}\right\} \\
y_{i}^{*}=X_{i}^{\prime} \delta+u_{i} \quad u_{i} \sim N\left(\begin{array}{ll}
0 & \sigma^{2}
\end{array}\right) \\
y_{i}=\left\{\begin{array}{ll}
y^{*} & \text { if } y_{i}^{*}>0 \text { and } \quad d_{i}^{*}>0 \\
0 & \text { otherwise }
\end{array}\right\}
\end{gathered}
$$

Where, $d_{i}{ }^{*}$ is a unobservable variable describing $i t h$ households' decision to participate in the teff output market as seller $\left(d_{i}\right)$, is a latent (unobservable) variable describing $i t h$ household extent of participation in the teff

\begin{tabular}{|c|c|c|c|}
\hline Variables & Type & Measurement & $\begin{array}{l}\text { Expected } \\
\text { effect }\end{array}$ \\
\hline \multicolumn{4}{|l|}{ Dependent variables } \\
\hline Market participation decision & Dummy & & \\
\hline Quantity of teff sold & Quintal & & \\
\hline \multicolumn{4}{|l|}{ Independent Variables } \\
\hline Sex of the household & Dummy & 1 if the household head is female; 0 otherwise & - \\
\hline $\begin{array}{l}\text { Educational level of the } \\
\text { household }\end{array}$ & Continuous & No of years schooling & + \\
\hline Family size & Continuous & Adult equivalent & $+/-$ \\
\hline Teff farming experience & Continuous & Teff farming experience & \\
\hline Equines owned & Continuous & Equines owned & \\
\hline Livestock owned & Continuous & TLU & + \\
\hline $\begin{array}{l}\text { Size of land allocated for teff } \\
\text { production }\end{array}$ & Continuous & Hectare & + \\
\hline $\begin{array}{l}\text { Distance to the nearest } \\
\text { market }\end{array}$ & Continuous & Kilometer & - \\
\hline Farm income & Continuous & ETB & + \\
\hline
\end{tabular}
output market, $y_{i}$ is the observed variable(actual.quantity of

teff sold by household i), $W_{i}^{\prime}$ and $X_{i}^{\prime}$ are vector of variables explaining the participation decision and extent of participation decision respectively, $\beta$ and $\delta$ are vectors of parameters to be estimated, vi and ui are respective error terms assumed to be independent and normally distributed.

Table 1. Description of variables hypothesized to affect both market participation decision and intensity of teff sale. 


\begin{tabular}{|c|c|c|c|}
\hline Variables & Type & Measurement & $\begin{array}{l}\text { Expected } \\
\text { effect }\end{array}$ \\
\hline Access to credit & Dummy & $\begin{array}{l}1 \text { if the household head has access to credit; } 0 \\
\text { otherwise }\end{array}$ & + \\
\hline Non-farm income & & ET Birr & - \\
\hline $\begin{array}{l}\text { Frequency of extension } \\
\text { contact }\end{array}$ & $\begin{array}{l}\text { Continuous } \\
\text { Discrete }\end{array}$ & Frequency & + \\
\hline Cooperative membership & Dummy & $\begin{array}{l}1 \text { if the household head is Member of } \\
\text { cooperatives; } 0 \text { otherwise }\end{array}$ & + \\
\hline
\end{tabular}

\section{RESULTS AND DISCUSSION}

The result of the survey indicates that out of total 202 sample households, $148(73.27 \%)$ households were teff market participants and 54(26.73\%) households were non participants of teff market. Group comparisons of teff market participants and non-participants was compared using t-test for continuous variables and $\mathrm{chi}^{2}$-test for dummy variables, and the results are presented in the consecutive tables.

As indicated in Table 2, out of total sample respondents, $152(75.24 \%)$ were male-headed and 50(24.75\%) were female-headed households. Among market participants, male headed and female headed households constitute $79.60 \%$ and $54 \%$ respectively. Out of non-participants, $20.39 \%$ were male headed while the remaining $46 \%$ were female headed households. Regarding cooperative membership, 95(47.02\%) of the sample households were members of cooperatives and $107(52.97 \%)$ were not organized under cooperatives. The chi $^{2}$ (Pearson chi ${ }^{2}$ (1)) test result among market participants and non-participants indicate the existence of significant difference between groups in terms of sex of household head and cooperative membership (Table 2). These indicate that market participants are more in number than non-participants in terms of the different categories and this relationship is real.

Table 2. Dummy variables of sample household heads

\begin{tabular}{|c|c|c|c|c|c|c|c|}
\hline Variables & rticip & $\%$ & $\begin{array}{c}\text { Non- } \\
\text { participant } \\
\mathrm{N}\end{array}$ & $\%$ & Total & $\%$ & $\chi^{2}-$ value \\
\hline \multicolumn{8}{|c|}{$\begin{array}{l}\text { Sex of household } \\
\text { head }\end{array}$} \\
\hline Female & 27 & 54 & 23 & 46 & 50 & 24.75 & $12.5941 * * *$ \\
\hline Male & 121 & 79.60 & 31 & 20.39 & 152 & 75.24 & \\
\hline \multicolumn{8}{|c|}{$\begin{array}{l}\text { Cooperative } \\
\text { membership }\end{array}$} \\
\hline Yes & 89 & 93.68 & 6 & 6.31 & 95 & 47.02 & $38.1696 * * *$ \\
\hline No & 59 & 55.14 & 48 & 44.85 & 107 & 52.97 & \\
\hline \multicolumn{8}{|c|}{ Access to credit } \\
\hline Yes & 42 & 80.76 & 10 & 19.23 & 52 & 25.74 & 0.4422 \\
\hline No & 106 & 70.66 & 44 & 29.33 & 150 & 74.26 & \\
\hline
\end{tabular}

***and ** indicate significance at $1 \%$ and $5 \%$ respectively

Source: Own survey result, 2018

Two-group mean-comparison test of continuous variables used in the study revealed that there was a significant mean difference between market participants and non-participants (Table 3). Accordingly, the average age of participants was 43.75 years, while for non-participants it was 42.89 years. With regards to the educational level of sample household heads, the average number of formal schooling years completed for participants was 4.56 years and for non-participants, 3.22 years and for the total sample 4.23 years. The mean difference in educational level of household head among market participant and non-participant is statistically significant at $1 \%$ significance level.

The average family size in adult equivalent for the market participants was found to be 3.28 , while for nonmarket participants was found to be 6.33 and for total sample 4.02 which are slightly lower than national mean of 5 members per household (FAO, 2015). The mean difference in family size among market participant and nonparticipant is statistically significant at $1 \%$ significance level. The analysis of survey data depicts that the average size of land allocated under teff for market participants was 0.85 ha; while for non-participant was 0.64 ha. The Ttest of variability between the groups showed that there was a statistically significant difference in terms of size of land allocated for teff between participants and non-participants at $1 \%$ significance level. The average area of land under teff production by sample households was 0.80 hectare with standard deviation of 0.43 (Table 3 ). The 
average total land size owned by the sample households was 1.40 hectare with standard deviation of 0.96 . This land holding size in the area is equal to average national land holding size of about 1.4 ha per household stated in CSA and WB (2013). In the district, mixed crop and livestock farming system is dominantly used by farm households. Livestock resources are useful in the livelihoods of smallholders; oxen are the major contributors to crop production by serving as a draft power. Farmers in the study area used oxen to undertake different agronomic practices, out of which ploughing and threshing are the major ones. The mean difference in livestock owned among market participant and non-participant is significant at $1 \%$ significance level. The mean livestock holding by sample households excluding equines in TLU for participant and non-participant was 4.82 and 3.46 respectively, and 4.49 for total sample households (Table 3).This livestock holding in the area is higher than average national livestock holding of about 2 TLU per household stated in FAO (2015).

In the study areas equines are used as a means of transport by smallholder farmers. Equines provide transport services for farm inputs from market to home, harvested farm produce from field to threshing center and for marketing of output. The mean difference in equines owned among market participant and non-participant is statistically significant at $1 \%$ significance level in (Table 3 ). The mean equines owned by sample households in TLU for participant and non-participant were 1.45 and 1.07 respectively, and 1.35 for total sample households. Agricultural extension service provisions on production and marketing have direct influence on the production and marketing behavior of the farmers. The agricultural extension service providers in the district are office of agriculture experts, development agents and researchers. The major extension services provided in relation to teff production includes: improved varieties of teff, row planting, input use, soil and water conservation, harvesting, post-harvest handling and marketing of teff. The mean difference in extension contact among market participant and non-participant was statistically significant at $1 \%$. The average frequency of extension service provided for participant and non-participant were 2.18 and 1.18 and for sampled households was 1.94 days/year (Table 3). The mean distance from the nearest market for the whole sample was 6.29 kilometers. The mean distance from the nearest market for market participants was 5.63 kilometers while it was 8.34 kilometers for non-participants. Ttest result shows that, there was statistically significant difference between participants and non-participants in distance from the nearest market at $1 \%$ significance level (Table 3 )

Table 3. Continuous variables of sample respondents

\begin{tabular}{lllllc} 
Variables & Participant & Non- Participant & Total & Std. Dev. & t-value \\
\hline & $\mathrm{n}=148$ & $\mathrm{n}=54$ & $\mathrm{~N}=202$ & & $-3.4903^{* * *}$ \\
Education level & 4.56 & 3.22 & 4.23 & 2.39 & $8.6827^{* * *}$ \\
Family size & 3.28 & 6.33 & 4.02 & 2.50 & -0.6852 \\
Farming experience & 8.29 & 7.79 & 8.17 & 4.42 & $-3.3678^{* * *}$ \\
Livestock owned & 4.82 & 3.46 & 4.49 & 2.51 & $-2.1992^{* * *}$ \\
Equines owned & 1.45 & 1.07 & 1.35 & 1.06 & $-3.0557^{* * *}$ \\
Size of land under teff production & 0.85 & 0.64 & 0.80 & 0.43 & $9.0058^{* * *}$ \\
Distance to the nearest market & 5.63 & 8.34 & 6.29 & 2.17 & $-6.1149^{* * *}$ \\
Frequency of extension contact & 2.18 & 1.18 & 1.94 & 1.08 & 0.0689 \\
Non-farm income & 4218.92 & 4157.40 & 4202.48 & 3930.2 & \\
\hline
\end{tabular}

Source: Own survey result, 2018

Symbols: ***,**and * indicates significant at $1 \%, 5 \%$ and $10 \%$ levels, respectively

\section{Econometric Results}

The results for factors affecting decision to participate in wheat output market and intensity of wheat sale are displayed in Table 4. Diagnostic test for multicollinearity shows that, the mean VIF of explanatory variable included in the model was 1.33 indicating that there was no serious problem of multicollinearity. The Wald chisquare value of 67.17 for market participation decision model is statistically significant at $1 \%$ indicating that at least one of the explanatory variables included in the model jointly explain the probability of participating in teff output market.

Sex of the household head being female was found to negatively influence the teff market participation at $10 \%$ significance level. The marginal effects showed that being female headed household decrease the probability of being participant by $5.77 \%$ as compared to male headed households. This result was due to the fact that activities accomplished at home like cooking, washing and child care fall upon the females. This specifies that empowering of female household head by proving a continuous and practical training on teff production and marketing is crucial to improve teff market participation. This result is in line with the findings of Leykun and Jemma (2014) and Tekalign (2014) which found that male headed households have a better access to information that would provide them with better ability to manage their farms and produce more output for market as compared to female headed households.

Education level affected probability of market participation positively and significantly at $1 \%$ significance 
level. One year increases in household head's education increase the probability of participation in teff output market as seller by $3.45 \%$. The result is consistent with the findings of Aman et al. (2014) and Yalew (2016) that states educated household head can have better market networking and bargaining power and good managerial skill of enterprises and their tendency to accept different agricultural technologies is high, so that they can produce more surpluses for market. Family size measured as adult equivalent was found to have negative and significant influence on teff market participation and intensity of participation at $1 \%$ and $10 \%$ significance level. The results shows that as the member of household increased by one adult equivalent decrease the probability of being market participant by $2.72 \%$ and decrease the quantity of teff marketed by 0.247 quintals. This result is expected because households with more family size tend to consume more of teff output produced and less is available for sales. This result is similar with findings of Efa et al. (2016) and Girma (2015) that showed that the larger household size consumes more output of teff produced, have the lower marketed surplus and less is available for sales.

Size of land under teff production was positively and significantly affects the teff market participation and intensity of participation at $10 \%$ and $1 \%$ significance level. The result shows that allocating one additional hectare of land to teff production would increase the probability of being market participant by $15.7 \%$ and quantity of teff marketed by 6.33 quintal. This result implies that those households allocating one more additional hectare of land from self-owned, by rented-in or shared-in land raises the probability of market participation. This show that larger area allocated to production increases the quantity of produce available for sale. The result of Efa et al. (2016) a Leykun and Jemma (2014) and Chanyalew et al. (2011) confirm this result. Number of livestock owned measured in TLU was positively and significantly contribute to the teff market participation at $1 \%$ significance level. The marginal effect indicates that excluding equines, increasing the number of livestock by one TLU increase the probability of being market participant by $2.4 \%$. This is due to the positive impact of livestock on the crop production enterprises by providing cash to purchase improved seed and in-organic fertilizer for teff production, and oxen serve as a traction power. This result is in line with Adam and Dawit (2015) and Tadele et al. (2017) found that the positive effect of livestock ownership on the crop output market participation increases due to significant effect on production. The result shows that frequency of extension contacts significantly and positively related with probability of teff market participation at $1 \%$ significant level. The marginal effect shows that an increase in frequency of extension contact by one day would increase the probability of being market participation by $4.18 \%$. This result implies that the technical advice provided for farmers by development agent, experts of agriculture and researchers on teff production (on improved seed, fertilizer application, row planting) and teff marketing. This indicates the importance of professional advice on being commercial farmer. This result is consistent with the findings of Tekalign (2014) and Girma (2015) who found that extension contact and advice significantly and positively influence crop commercialization and marketed surplus of teff, respectively.

Distance to the nearest market negatively and significantly influences household's decision to participation in teff output market at $1 \%$ significant level. Distance to the market proxies accessibility of the markets to smallholders. The size effect implies that, when the household is located one kilometer away from the nearest market, the probability of participation in teff output market decreases by $2.63 \%$. As Martey et al. (2012) cited in Benjamin (2013), distance to market is an indicator of travel time and cost. The longer the distance of the market, it is more costly and time consuming to travel with output forcing smallholder farmers to hold more output particularly which is common in rural areas where transportation facility is poorly developed. Alternatively, as the distance from the nearest market increases, transport costs increase and this discourages smallholder farmers and their probability of participation in a market decreases. This result is consistent to findings of Gani and Adeoti (2011) who studied market participation among farmers which found being closer to nearest market enhances probability of market participation. The finding is also in agreement with findings of Berhanu and Moti (2010), Aman et al. (2014), Agwu et al. (2013), Yaynabeba and Tewodros (2013), and Berhanu et al. (2009).

As expected income obtained from non -farm activities influenced the intensity of market participation negatively and statistically at $1 \%$ significant level. This shows that an increase in the amount non-farm income by one thousand ET birr, quantity of teff marketed decreases by 0.0791 quintal. This result is due to the reason that households obtained income from non-farm activities were not encouraged to cultivate teff on more area of land and they used the amount produced for home consumption. This result is supported by the findings of Yassin (2016) who found negative effect of non-farm income on probability of potato market participation and level of potato sale. 
Table 4. Result for factors affecting probability and intensity of teff sale

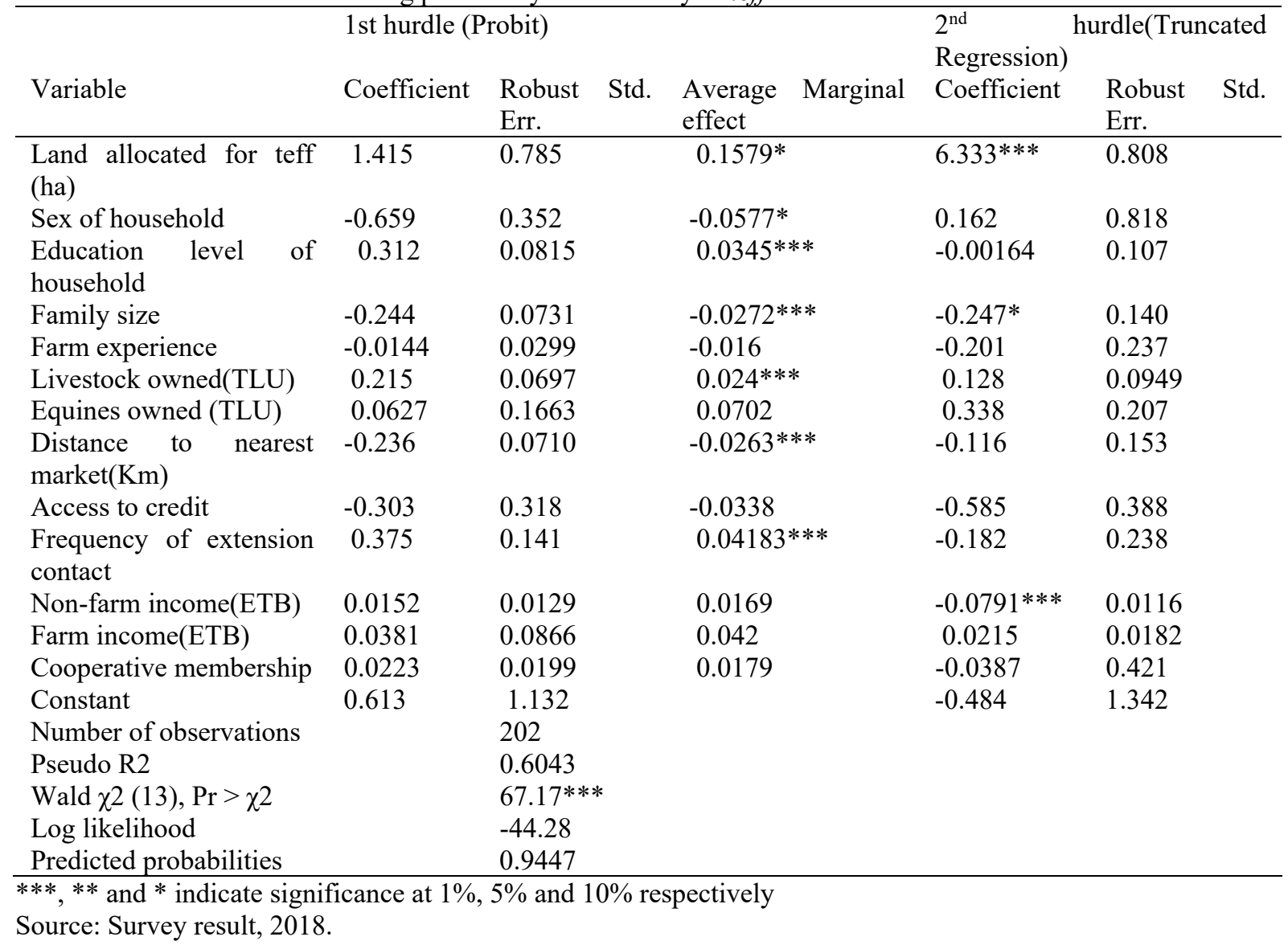

\section{Conclusion and Policy implications}

In this study factors affecting market participation decision and intensity of participation of households in Shashamane district were analyzed. Double hurdle estimation results revealed that, household decision to participate in teff market positively and significantly affected by educational level, livestock owned, land under teff, number of contact with agricultural extension agents Moreover, factors such as sex of household head and family size (adult equivalent) were found to negatively and significantly effect on probability of teff market participation. Household intensity of participation was also affected positively and significantly by size of land under teff production while it was negatively and significantly affected by family size (adult equivalent) and nonfarm income.

Support given to female household head and empowering of female household head through training and supply of improved technology that encourage them to participate in teff marketing is indispensable. Designing of policies that encourage provision of adequate and effective formal education to the rural farming households and to the study area in particular enhances households' likelihood of market participation. This can be done by regional and local government through strengthening the existing education provision system in order to enhance households' market participation, rural health extension should be strengthened on promoting family planning based on interest of farmers by showing its negative impact is important in the study areas. In addition, provision of rural employment opportunities is essential to reduce high dependence on farm output and to increase the proportion outputs sold.

Efforts are required in improving number of livestock ownership is essential for smallholder farmers as source of cash to purchase improved seed and inorganic fertilizers and provide a traction power to enhance market participation of teff producers. Proper utilization of land resource requires intensifying the farm practices through provision of sustainable and timely supply of inputs, increasing the farmers' awareness on agronomic practices like row planting and proper application of inputs helps the farmer to produce and supply more teff to the market. joint effort of development agent, agricultural experts, researchers and other stakeholders on identifying and solving problems, availing of new agricultural technology, transfer of improved technology and information to farmers are compulsory to enhance market participation. Interventions intended at raising the efficiency of farmers to reduce farmer's involvement in non-farm activities and changing the attitudes of farmers to use cash income obtained from non-farm activities to strengthen their agricultural production and market orientation is crucial. 


\section{REFERENCES}

Adam Bekele and Dawit Alemu. 2015. Farm-level determinants of output commercialization: In haricot bean based farming systems. Ethiop. J. Agric. Sci. 25: 61-69.

ADEA (Association for the Development of Education for Africa). 2014. Ethiopia country report for the Ministerial Conference on Youth Employment, 21-23 July 2014.

Agwu N.M., Anyanwu C.I.And Mendie E.I. 2013.Socio-economic determinants of commercialization among smallholder farmers in Abia State, Nigeria. A paper presented at The 4th InternationalConferenceof the African Association of Agricultural Economists, Hammamet, Tunisia.

AID (Agency for International Development). 2018. Assessments of commodity and trade issues. grain and feed annual report, Ethiopia.

Aman Tufa, Adam Bekele, and Lemma Zemedu. 2014. Determinants of smallholder commercialization of horticultural crops in Gemechis district, West Hararghe zone, Ethiopia. African Journal of Agricultural Research, 9(3): 310-319.

ATA (Agricultural Transformation Agency). 2015. Annual report on agricultural transformation agenda.

Benjamin A. 2013. Market participation of smallholder farmers in the Upper West region of Ghana. MSc. Thesis submitted to University of Ghana, Legon.

Berhanu Gebremedhin and Moti Jaleta. 2010. Commercialization of smallholders: is market participation enough?.2010 AAAE third conference/AEASA48th conference, September 19-23, 2010, Cape Town, South Africa.No. 96159.African Association of Agricultural Economists (AAAE) and Agricultural Economics Association of South Africa (AEASA).

Chanyalew Seyoum, Tesfaye Lemma, and Ranjan S. K. 2011. Factors determining the degree of commercialization of smallholder agriculture: The case of potato growers in Kombolcha district, East Hararghe, Ethiopia. JAD, 2 (1).

Cragg, J.G. 1971. Some statistical models for limited dependent variables with application to the demand for durable goods.Econometrica, 39(5): 829-844.

CSA (Central Statistical Agency). 2013. Agricultural sample survey report on area and production of major crops (Private peasant holdings, meher season 2012 / 2013(2005 E.C.). Addis Ababa, Ethiopia, the FDRE Statistical Bulletin.

CSA (Central Statistical Agency). 2017. Agricultural sample survey: Report on area and production of major Crops.

CSA (Central Statistical Agency). 2018. Agricultural sample survey 2017/2018 (2010 E.C): Report on area and production of major crops, Volume-I. Addis Ababa, Ethiopia.

Efa Gobena, Degye Goshu, TinsaeDemisie and Tadesse Kenea. 2016. Determinants of market participation and intensity of marketed surplus of teff producers in Bacho and Dawo Districts of Oromia, Ethiopia. Journal of Agricultural Economics and Development, 5(2): 20-32.

FAO (Food and Agricultural Organization of the united Nations). 2015. Ethiopia country highlights on irrigation market brief. UNFAO, Rome, Italy.

Gani, B.S. and Adeoti, A. I. 2011. Analysis of market participation and rural poverty among farmers in Northern Part of Taraba State, Nigeria.Journal of Economics, 2(1): 23-36.

Gebreslassie Atsbaha and Bekele Tessema. 2012. A review of Ethiopian agriculture: Roles, policy and small-scale farming systems. Country analysis: Ethiopia and D.R. Congo,37.

Girma Alemu. 2015. Market performance and determinants of marketed surplus of teff in Bacho Woreda of South West Shewa Zone, Oromia National Regional State. Msc Thesis, Haramaya University, Haramaya, Ethiopia.

Leykun Birhanu and Jema Haji. 2014. Econometrics analysis of factors affecting market participation of smallholders farming in central Ethiopia. Journal of Agricultural Economics and Extension and Rural Development, 2(6): 84-104.6000p

Martey, E., Al-hassan, R. M. and Kuwornu, J. K. M. 2012.Commercialization of smallholder agricultures in Ghana. A tobit regression analysis. African Journal of Agricultural Research, 7(14): 2131-2141.

Mmbando F.E., Edilegnaw Wale and Baiyegunhi Lloyd J.S. 2015.Determinants of smallholder farmers' participation in maize and pigeon pea markets in Tanzania.Agrekon, 54 (1): 96-119.

NBE (National Bank of Ethiopia).2018.Annual report of 2017-18. Addis Ababa, Ethiopia

SHDAO (Shashamane District Agriculture Office). 2019. Socio- economic profile of Shashamane districts.

Tadele Mamo, Wudineh Getahun, AgajieTesfaye, Ali Chebil, Tesfaye Solomon, Aden AwHassan, TolessaDebele and Solomon Assefa. 2017. Analysis of wheat commercialization in Ethiopia: The case of SARD-SC wheat project innovation platform sites. African Journal of Agricultural Research, 12(10): 841-849.

Tekalign Diyana. 2014. Determinants and welfare outcomes of commercialization of smallholders' farming: The case of Anchar woreda, West Hararghe, Ethiopia. MSc thesis submitted to School of Graduate Studies of Haramaya University, Haramaya.

Yalew Mazengia. 2016. Smallholders commercialization of maize production in Guangua district, Northwestern Ethiopia. World Scientific News, 58: 65-83. 
Yamane, T. 1967. Statistics: An Introductory Analysis, 2nd Edition. Harper \& Row, Publisher, New York. pp. 919.USAID (United States Age

Yaynabeba Abayneh and Tewodros Tefera. 2013. Factors influencing market participation decision and extent of participation of haricot bean farmers in Meskan district, Ethiopia. International journal of management and development studies, 2(8): 2320-0685.

ZerihunWondifraw, Wakiaga, J. and Kibret Haile. 2016. African Economic Outlook, Ethiopia. 